\title{
MINERÍA DEL LITIO Y ACUMULACIÓN POR DESPOSESIÓN. EL CASO DE SALAR DEL HOMBRE MUERTO (1999-2016)
}

\author{
Sebastián Gómez Lende ${ }^{1}$
}

\section{RESUMO}

Recentemente, a mineração do litio tornou-se indispensável para a reprodução do sistema capitalista contemporâneo. Peça chave do modelo (neo) extrativista vigente na América Latina, este uso do território não tem sido objeto da atenção e interesse académicos, principalmente a respeito de sua relação com o ciclo de acumulação por desapropriação, iniciado durante a década de 1990 e continuado até a atualidade. Este trabalho analisa, portanto, o boom da atividade na Argentina entre 1999 e 2016, tomando como estudo de caso o mais antigo e importante depósito do país: Salgar do Homem Morto. À luz das categorias e dimensões da acumulação por desapropiação propostas pela literatura, o artigo revela e explica as diversas dinâmicas de expropriações geográfica, económico-política e sócio-ecológica do modelo e seus correlatos de fragmentação sócio-territorial e pilhagem dos bens comuns locais.

Palavras-chave: mineração do litio; acumulação por desapropriação; Salgar do Homem Morto; Argentina, províncias de Catamarca e Salta.

\section{LITHIUM MINING AND ACCUMULATION BY DISPOSSESSION IN ARGENTINA: THE CASE OF SALAR DEL HOMBRE MUERTO (1999-2016)}

\section{ABSTRACT}

Recently, lithium mining has become indispensable for the contemporary capitalist system's reproduction. Considered as a key part of the current (neo) extractivist pattern in Latin America, this use of the territory has not received the attention and academic interest it deserves regarding to the accumulation by dispossession's cycle started during the 1990s and continued until the present. Seeking to cover this gap, this work analyzes the boom of the activity in Argentina between 1999 and 2016 by taking as a case study the oldest and most important lithium mine of the country: Salar del Hombre Muerto. In light of the accumulation by dispossession's categories and dimensions proposed by the literature, the article reveals and explains the diverse geographic, economic-political and socio-ecological expropriation dynamics, as well as the social and territorial fragmentation and the looting of the local commons produced by this pattern.

Keywords: lithium mining; accumulation by dispossession; Salar del Hombre Muerto; Argentina, provinces of Catamarca and Salta.

\footnotetext{
${ }^{1}$ Doctor en Geografía. Investigador Adjunto del Consejo Nacional de Investigaciones Científicas y Técnicas (CONICET). Instituto de Geografía, Historia y Ciencias Sociales (IGEHCS), CONICET/Universidad Nacional del Centro de la Provincia de Buenos Aires. Ciudad de Tandil (CP: 7.000), Provincia de Buenos Aires, Argentina. Email: gomezlen@fch.unicen.edu.ar

Estudos Geográficos, Rio Claro, 15(1): 157-183, jan./jun. 2017 (ISSN 1678-698X)

http://www.periodicos.rc.biblioteca.unesp.br/index.php/estgeo
} 
Minería del litio y acumulación por desposesión...

\section{INTRODUCCIÓN}

Aunque recientemente la minería del litio ha cobrado creciente e inusitada relevancia a escala mundial -al punto de tornarse estratégica (incluso indispensable) para la reproducción del sistema capitalista contemporáneo-, sus implicancias respecto del papel que desempeña en la acumulación por desposesión no han sido suficientemente estudiadas y debatidas en América Latina. Incluso en la Argentina, país donde la minería metalífera emerge como un uso del territorio preñado de álgida conflictividad socio-ambiental e irreconciliables controversias políticas, el boom del litio ha permanecido relativamente inadvertido en lo que atañe a sus dinámicas expropiatorias. La inmensa mayoría de los estudios académicos acerca de la relación entre minería metálica y acumulación por desposesión se han focalizado sobre todo en la minería del oro, el cobre y la plata, en tanto que los análisis sobre el auge del litio no han derivado en abordajes integrales de los dispositivos del saqueo presentes en los proyectos actualmente en fase de explotación; al contrario, han situado el eje de la discusión en la reciente oleada de inversiones extranjeras para exploración de nuevos yacimientos, el debate entre quienes propugnan la exportación en bruto de la materia prima a extraer y quienes impulsan la industrialización nacional de esas riquezas y, en menor medida, el avasallamiento de los derechos de las comunidades aborígenes y las potenciales implicancias socio-ambientales que tales emprendimientos podrían acarrear.

Procurando cubrir esa área de vacancia, este artículo analiza el desarrollo de la minería transnacional del litio en la Argentina durante el período 1999-2016, tomando como estudio de caso al más antiguo e importante yacimiento en operación en el país: Salar del Hombre Muerto. La hipótesis de trabajo sostiene que esta actividad -pieza clave del modelo (neo)extractivista vigente en la Argentina- solapa, reúne y combina buena parte de las categorías y dimensiones analíticas de la acumulación por desposesión oportunamente identificadas o propuestas por la literatura. Orientado a demostrar empíricamente tal aserto, el artículo se nutre de diversas fuentes, entre las cuales merecen destacarse la consulta de bibliografía académica especializada, datos estadísticos oficiales e información periodística.

El trabajo comienza presentando una apretada síntesis teórico-conceptual acerca de las relaciones entre espacio geográfico, usos del territorio, acumulación por desposesión y extractivismo. Seguidamente, se describe el boom del litio a escala mundial, señalando el papel que desempeña en la economía capitalista globalizada, los principales actores del sector y la inserción de la Argentina en este mercado. Núcleo del artículo, el tercer apartado explica los múltiples nexos y relaciones forjados entre la minería transnacional del litio a gran escala y los distintos mecanismos de acumulación por desposesión, recuperando para ello las dimensiones propuestas por Harvey (2004, p. 116-118) y Machado Aráoz (2011, p. 166-173); así pues, el primer sub-acápite de esta sección abordará los fenómenos asociados a los dispositivos de expropiación geográfica (privatización de tierras, apropiación colonial, neocolonial e imperial de bienes comunes, extranjerización del patrimonio público, configuración de enclaves exportadores, dinámica del mercado laboral, falacia del desarrollo local), en tanto que el segundo explicará las dimensiones económico-política y socio-ecológica del despojo (normas públicas que alimentan la rentabilidad empresarial permitiendo la remesa de recursos financieros hacia los centros mundiales de poder, degradación y contaminación del hábitat,

Estudos Geográficos, Rio Claro, 15(1): 157-183, jan./jun. 2017 (ISSN 1678—698X)

http://www.periodicos.rc.biblioteca.unesp.br/index.php/estgeo 
acaparamiento y transferencia al exterior de bienes y servicios ambientales como el 'agua virtual', etc.). Finalmente, se presentarán las conclusiones a las que el trabajo ha arribado.

\section{USOS DEL TERRITORIO, ACUMULACIÓN POR DESPOJO Y EXTRACTIVISMO}

Sinónimo de territorio usado, el espacio geográfico es un conjunto solidario, indisociable y contradictorio de sistemas de objetos y sistemas de acciones, mediados por normas (SANTOS, 1996, p. 39; SANTOS y SILVEIRA, 2001, p. 21). Originados a partir de las lógicas del orden global y la división internacional del trabajo, muchos de los usos hegemónicos del territorio desarrollados en los países periféricos suelen reunir dos rasgos singulares y complementarios: por un lado, operan como formas o modalidades de lo que Harvey (2004, p. 116) denomina "'acumulación por desposesión"; por el otro, integran la matriz del llamado "modelo extractivista" (GUDYNAS, 2009, p. 187-194).

Originado en la noción de "acumulación primitiva" u "originaria" -el acto histórico de despojo violento que instauró las relaciones sociales capitalistas a escala mundial y fue crucial para la formación del stock de capital necesario para la Revolución Industrial europea (MARX, 1968, p. 221)-, el concepto de acumulación por desposesión remite a la continuidad de aquellas prácticas depredadoras (HARVEY, 2004, p. 122) que, en cada período histórico, suponen nuevos avances del capital sobre recursos y población hasta entonces ajenos a su lógica. Sistemático, ese omnipresente proceso de privatización y mercantilización de bienes comunes permite que el sistema sortee sus propias crisis de hiperacumulación mediante soluciones o ajustes espacio-temporales basados en el imperialismo (HARVEY, 2004, p. 114).

El extractivismo, por su parte, puede ser definido como un modelo de acumulación basado en la conversión de bienes comunes en mercancías, la explotación intensiva de grandes volúmenes de recursos naturales a un ritmo acelerado incompatible con los tiempos de reposición de la naturaleza, el escaso o nulo grado de procesamiento (industrialización) local/regional de los bienes así extraídos, y la exportación de materias primas para abastecer la industria y/o el consumo de los países centrales, generando rentas extraordinarias captadas por agentes externos (BURCHARDT \& DIETZ, 2014, p. 468). El patrón de organización espacial de los usos extractivos del territorio estructura y reproduce una matriz socio-productiva desequilibrada y excesivamente especializada, basada en economías de enclave -o "colonias-commodities" (MACHADO ARÁOZ, 2013a, p. 32)- tanto acotadas como extensas cuyo desarrollo y expansión agrava la subordinación/dependencia económico-política y los impactos socio-ambientales sufridos por las regiones involucradas en el modelo (GUDYNAS, 2009, p. 199-207). Ciertamente, la relación entre extractivismo y acumulación por desposesión es muy estrecha: el primero opera como piedra angular de la segunda, y ambos despojan a territorios y grupos sociales de sus bienes comunes y derechos históricamente adquiridos. Los usos extractivos del territorio constituyen, de hecho, la pieza clave del actual ciclo de acumulación por desposesión en América Latina iniciado por el auge del neoliberalismo durante la década de 1990 y continuado por la estrategia neo-desarrollista implementada a comienzos del Siglo XXI. Sustentado en actividades tan disímiles como el agro-negocio, la minería, los hidrocarburos, la Estudos Geográficos, Rio Claro, 15(1): 157-183, jan./jun. 2017 (ISSN 1678—698X) http://www.periodicos.rc.biblioteca.unesp.br/index.php/estgeo 
foresto-industria y la pesca, la matriz (neo)extractivista latinoamericano reúne y combina prácticamente todas las dimensiones de la acumulación por desposesión identificadas por Harvey (2004, p. 116-118). Así pues, se solapan y convergen la mercantilización y privatización de la tierra, el desplazamiento de granjas familiares, la expulsión de campesinos y aborígenes, la apropiación colonial, neocolonial e imperial de bienes comunes, la eliminación de formas de producción y consumo precapitalistas, la mercantilización y cientifización de la naturaleza, el desmantelamiento de los marcos de protección laboral/ambiental, la biopiratería, los derechos de propiedad intelectual sobre material genético y plasma de semillas y la degradación del hábitat, el auge del sistema financiero, los relictos de la esclavitud, y la privatización y/o extranjerización del patrimonio público y/o nacional.

La relación entre (neo)extractivismo y acumulación por desposesión puede ser sintetizada por tres dinámicas: la expropiación geográfica, que convierte a los espacios locales en enclaves exportadores técnica y políticamente subordinados a cadenas mundiales de valor verticalmente controladas por el capital transnacional concentrado, desintegrando su matriz productiva, eliminando su diversidad territorial y social y destruyendo su coherencia interna; la expropiación económica, basada en reformas normativo-institucionales que recomponen la tasa de ganancia empresarial y ocasionan una descomunal transferencia de recursos hacia los centros mundiales de poder; y la expropiación ecológica, vinculada a la apropiación diferencial (y transferencia al exterior) de bienes ecológicos y servicios ambientales (MACHADO ARÁOZ, 2011, p. 166-173). Como resultado, los usos extractivos del territorio se vuelven -parafraseando a Santos y Silveira (2001, p. 132)- racionales sólo para los agentes hegemónicos beneficiados por ese modelo de organización espacial, a la vez que irracionales para todos los demás actores.

\section{EL BOOM DEL LITIO A ESCALA MUNDIAL Y LA INSERCIÓN DE LA ARGENTINA}

Originalmente descubierto en Suecia en 1817 y comercializado en los Estados Unidos a partir de 1898, el litio es un mineral metálico blando alcalino color blanco plata de amplia presencia en la naturaleza que puede ser hallado en salares, aguas marinas y termales, suelos desérticos y rocas sedimentarias, sedimentos arcillosos y yacimientos geotérmicos, petroleros y de minerales a los que se encuentra asociado -boro, potasio, magnesio, berilio, espodumeno, petalita, cuarzo, mica, feldespato-. Siendo el más ligero de todos los metales conocidos, el litio reúne ciertos rasgos que lo tornan apto para múltiples aplicaciones industriales: alto calor específico -el más elevado de todos los sólidos-; baja viscosidad; rápida oxidación y corrosión; reacción con el nitrógeno; insolubilidad en hidrocarburos; alta higroscopicidad; y elevado potencial electro-químico para la conducción de calor y energía. Como resultado de estas singulares propiedades, desde el Siglo XX su uso ha sido habitual en la industria de la cerámica, el esmalte y el vidrio, la fabricación de equipos de aire acondicionado, la lubricación de sistemas a altas temperaturas, la soldadura para latón, la producción de grasas lubricantes y aluminio, la separación de gases en la industria química y la fabricación de caucho sintético (MANRIQUE, 2014, p. 15-24; FARN-CEDIB, 2014, p. 12; ZÍCARI, 2015, p. 13).

Otrora limitado a las aplicaciones citadas, el mercado del litio cobró renovado impulso a partir de la década de 1950 a raíz de la demanda de dos actores clave: los laboratorios farmacéuticos y la industria bélica norteamericana. Por un lado, este Estudos Geográficos, Rio Claro, 15(1): 157-183, jan./jun. 2017 (ISSN 1678-698X) http://www.periodicos.rc.biblioteca.unesp.br/index.php/estgeo 
mineral se convirtió en un ingrediente esencial para la producción de fármacos orientados al tratamiento de patologías psiquiátricas (depresión unipolar, síndrome bipolar, bulimia, insomnio, trastornos de hiperactividad y ansiedad, ataques de pánico, adicciones). Por otro lado, el litio asumió un rol estratégico en el desarrollo de múltiples aplicaciones militares y aeroespaciales, tales como la fabricación de combustibles para cohetes, la purificación del aire en submarinos y naves espaciales, la elaboración de aleaciones especiales para fuselajes y motores de aviones y la producción de armamento nuclear (AGUILAR y ZELLER, 2012, p. 8-12; MANRIQUE, 2014, p. 15-24; NACIF, 2014, s/p; ZÍCARI, 2015, p. 13). No obstante, hasta 1970 los volúmenes de extracción y comercialización del litio a escala mundial permanecieron en niveles relativamente modestos y estables, dependiendo sobre todo de la explotación de las minas estadounidenses y australianas de petalita y, en menor medida, los salares chilenos.

El verdadero boom del litio se desataría recién entre mediados de la década de 1990 y la actualidad, de la mano de la maduración de la revolución informática y de las telecomunicaciones primero y de la eclosión de la revolución nano-tecnológica después. Concretamente, este mineral comenzó a desempeñar un papel prácticamente irremplazable en la producción de baterías primarias de litio -como las que alimentan calculadoras manuales, relojes y dispositivos médicos- y, sobre todo, de baterías secundarias recargables Li-Ion (o ión-litio), las cuales sustituirían a los ya obsoletos acumuladores alcalinos elaborados a base de níquel y cadmio. Dado que las baterías Li-lon permitieron a las compañías tecnológicas reducir sus costos de producción y ofrecer mejores prestaciones, el litio acabó tornándose indispensable para la producción de teléfonos celulares, computadoras portátiles, agendas electrónicas, tablets, cámaras fotográficas y filmadoras digitales, marcapasos, satélites y naves espaciales (REDAJ, 2011, p. 2; FARN-CEDIB, 2014, p. 12).

Si en 1995 las baterías a base de litio representaban menos del $5 \%$ del mercado, en 2008 ya daban cuenta del 58\%. En apenas una década (1996-2005), el volumen de litio utilizado para la fabricación de teléfonos celulares creció 94 veces de 1,8 a 170 millones de toneladas-, y el contenido por las computadoras portátiles, 30 veces -de 3,3 a 99 toneladas- (BRUCKMAN, 2012, p. 87). Como resultado, la producción de baterías recargables se convirtió en el principal destino de este mineral, en virtud del meteórico y exponencial crecimiento de la participación relativa de este rubro durante los últimos años $-7 \%$ en $1998,31 \%$ en $2014,39 \%$ a comienzos de 2017- (ZÍCARI, 2015, p. 14-16; MEyM, 2017, p. 7). Otro factor que indudablemente ha contribuido a tal situación ha sido la reestructuración de la industria automotriz transnacional, donde empresas como la estadounidense General Motors, las japonesas Toyota y Nissan, y las europeas Porsche, Mercedes Benz, Volvo y Renault buscan orientarse a la producción de vehículos a propulsión eléctrica (puros e híbridos). Si bien los autos eléctricos representan apenas el 0,68\% del mercado y la mayoría de estos vehículos no utilizan baterías Li-lon, se espera que las nuevas generaciones lo hagan masivamente debido a las presiones internacionales para la supuesta sustitución de los combustibles fósiles por 'energías verdes $^{\prime 2}$ y a las virtudes del litio para el almacenamiento de energía con niveles de potencia, autonomía y tiempos de recarga aceptables (ZíCARI, 2015, p. 18).

\footnotetext{
${ }^{2}$ Es habitual que el litio sea considerado el 'oro blanco de la energía' o, incluso, el 'petróleo del Siglo XXI'. Sin embargo, es importante destacar que las baterías a base de litio no producen energía -como sí lo hacen los motores a combustión-; sólo la almacenan. Además, la electricidad con la cual se abastecerían los nuevos automóviles aún continuaría siendo en gran parte provista por los combustibles fósiles (ZíCARI, 2015, p. 37) Estudos Geográficos, Rio Claro, 15(1): 157-183, jan./jun. 2017 (ISSN 1678-698X) http://www.periodicos.rc.biblioteca.unesp.br/index.php/estgeo
} 
Como consecuencia de estos cambios, el mercado internacional del litio sufrió una aguda reestructuración, plasmada en la sustancial expansión de la demanda, el consecuente aumento de los precios y la modificación del patrón espacial de la oferta del mineral. El consumo mundial se incrementó exponencialmente, pasando de apenas 100 toneladas de carbonato de litio equivalente en 1900 y sólo 5.515 toneladas en 1980 a 150.000-160.000 toneladas en 2011 (CEPAL, 1985, p. 56; AGUILAR y ZELLER, 2012, p. 27; SEVARES y KRZEMIEN, 2012, p. 133). Como resultado, el consumo internacional per cápita aumentó un $1.721 \%$ entre 1980 y 2011, pasando de 1,24 a 22,59 gramos de litio por habitante. Concomitantemente, los precios se incrementaron ostensiblemente. Si bien durante la década de 1990 la cotización internacional del litio se mantuvo relativamente estable -fluctuando entre 1.770 y 3.000 dólares por tonelada-, a partir de 2005 el brusco aumento de la demanda (motorizado básicamente por China) y el ciclo económico mundial de alza de los precios de las materias primas impulsaron su acelerado crecimiento, llevándola a alcanzar actualmente los 7.475 dólares (MEyM, 2017, p. 9).

El boom del litio reorganizó el mapa minero mundial. Si bien las reservas estimadas totales ascienden a 33 millones de toneladas concentradas en Bolivia, Chile, China, Estados Unidos, Argentina, Australia, Brasil, Canadá, Zimbabwe, Congo, Namibia, Rusia, España y Portugal, sólo el $40 \%$ de estos recursos (13 millones de toneladas) resulta objeto de una explotación económicamente viable (MEyM, 2017, p. 6). El creciente peso relativo de las baterías como destino final ${ }^{3}$ y la necesidad de las mineras transnacionales de reducir sus costos de producción desplazaron el centro de gravedad de la actividad desde los depósitos minerales de espodumeno y petalita de Australia, Zimbabwe, Namibia, Canadá, Brasil y Rusia a los salares localizados en el denominado 'triángulo del litio', un área de 43.000 km2 que abarca el sur boliviano, el norte chileno y la puna argentina. Con epicentro en el Salar de Uyuni (Bolivia), el Salar de Atacama (Chile) y los diversos salares de la puna salteño-jujeña-catamarqueña, este triángulo -o 'Arabia Saudita del litio', como lo dio en llamar la revista norteamericana Forbes- reúne el $55 \%$ de las reservas totales y el $85 \%$ de los recursos explotables en salmuera, siendo secundado por los lagos salinos de Nevada (Estados Unidos), Qinghai (China) y Zhabuye (Tibet) (FARN-CEDIB, 2014, p.11; NACIF, 2014, s/p; ZÍCARI, 2015, p. 21). Como resultado de la mayor densidad del recurso y la relativamente escasa inversión que requiere su explotación ${ }^{4}$, la extracción de litio en salmueras pasó de representar el $35 \%$ de la producción mundial en 1995 a significar el 86\% en 2007 (COCHILCO, 2009, p. 13).

Si bien controla la mayoría de las reservas mundiales $(27 \%)$, Bolivia aún no ha iniciado la extracción del recurso, razón por la cual Chile es actualmente el principal productor y exportador de litio. Secundado por Argentina, Bélgica y China, el país trasandino acapara el $44 \%$ de la extracción y representaba en 2016 el 59,1\% de las ventas externas, satisfaciendo así la tercera parte del consumo mundial de este mineral (TRADEMAP, 2017, s/p). En contraposición, China, Corea del Sur, Japón,

\footnotetext{
${ }^{3}$ En efecto, el litio proveniente de minas de petalita y espodumeno es principalmente requerido por la industria del vidrio y la cerámica, única que considera competitivos sus altos costos de producción (NACIF, 2014, s/p). Actualmente se considera que la única fuente de litio económicamente viable y suficientemente pura elaborar baterías para autos eléctricos son justamente los salares (SEVARES y KRZEMIEN, 2012, p. 135).

${ }^{4}$ La composición de litio de las salmueras oscila entre 200 y 2.000 partes por millón (ppm), frente al máximo de 100 ppm de los depósitos minerales. Asimismo, mientras que la explotación en yacimientos requiere trabajos de trituración, molienda, lixiviación, purificación y precipitación que encarecen la extracción (U\$S 4.500/ton), el litio de los salares se obtiene a partir del simple bombeo de la salmuera y su evaporación natural vía energía solar. Con menores costos de producción (U\$S 2.300/ton), este método deja un sedimento altamente concentrado rico en otros minerales valiosos -potasio, sulfato, boro- (ARÉVALO MOSCHELLA, 2015, p. 4).

Estudos Geográficos, Rio Claro, 15(1): 157-183, jan./jun. 2017 (ISSN 1678-698X)

http://www.periodicos.rc.biblioteca.unesp.br/index.php/estgeo
} 
Bélgica y Estados Unidos explicaban el $80,1 \%$ de las importaciones. Apenas tres países (China, Japón y Corea del Sur) consumían el 60,2\% del carbonato de litio comercializado en el mundo, dando cuenta -junto a sus re-exportadores (Singapur, Hong Kong, Indonesia) y los Estados Unidos- del $59,6 \%$ y el $83 \%$ de la exportación de baterías/pilas de litio y acumuladores de litio-ión, respectivamente (TRADEMAP, 2017, s/p).

El mercado del litio se encuentra fuertemente concentrado no sólo en términos geográficos, sino también corporativos: apenas un puñado de empresas mineras concentra casi la totalidad de la producción mundial, destacándose la chilena SQM, las estadounidenses Foote Minerals Corporation (FMC) y Silver Peak, la alemana Rockwood Lithium y la australiana Talison Minerals, recientemente adquirida por la china Sichuan Tianqui Lithium Industries y Rockwood. Dado que el suministro seguro, confiable y diversificado de litio se ha convertido en una prioridad para las compañías asiáticas de tecnología, son habituales en este sentido los fenómenos de fusiones empresariales y alianzas estratégicas; así pues, firmas transnacionales automotrices asiáticas como Toyota, Mitsubishi y Kores se han asociado a las empresas mineras, financiando sus proyectos para asegurarse una participación estable respecto del control del recurso (SEVARES y KRZEMIEN, 2012, p. 138).

Si bien en la Argentina los orígenes de la minería del litio se remontan a 1935 -año en que se inició la explotación de los yacimientos de Córdoba y San Luis-, este mineral recién cobraría importancia en el país a partir de la década de 1960 cuando, en el marco del comienzo de la era nuclear, los salares de la puna despertaron el interés de empresas estatales como la Dirección General de Fabricaciones Militares (DGFM) y la Comisión Nacional de Energía Atómica (CNEA). Considerando al mineral como un elemento crítico para la defensa nacional, la DGFM y la CNEA buscaron infructuosamente establecer la reserva fiscal sobre el recurso, desarrollando a la vez un ambicioso programa de exploración de las cuencas salinas de Jujuy, Salta y Catamarca que seleccionó como reservorio más relevante al Salar del Hombre Muerto. Posteriormente, la modificación en 1980 del Código de Minería que incorporaría al litio como recurso concesible al capital privado- y la falta de fondos públicos determinaron que en 1982 la DGFM abandonara el proyecto y licitara el yacimiento a la principal proveedora mundial del mineral: la estadounidense Lithium Corp. of America -actual FMC- (NACIF, 2014, s/p).

No obstante, la explotación del litio a gran escala del Salar del Hombre Muerto recién se iniciaría a finales del Siglo XX, luego de que el centro mundial de gravedad de la minería metalífera se desplazara hacia África y América Latina. Otrora prácticamente inexistente en la construcción histórica de la matriz productiva argentina, la minería metálica transnacional experimentaría así un intenso desarrollo en el país al ser favorecida por las reformas estructurales neoliberales de finales del Siglo XX y las políticas neodesarrollistas de principios del nuevo milenio. En consecuencia, la inversión extranjera directa en el sector minero en general creció exponencialmente, propiciando el meteórico crecimiento de las exportaciones de oro, plata, cobre, litio y, en menor medida, zinc, plomo, molibdeno, manganeso y cromo. Como resultado, el complejo minero metalífero actualmente representa el $2 \%$ del PBI y el 4,6\% de las exportaciones argentinas (MH-INDEC, 2017, p. 3).

Si bien en términos generales el litio explicaba en 2011 apenas el 1,14\% de la producción minera nacional (ZíCARI, 2015, p. 37), la Argentina es el primer país del mundo en materia de inversiones orientadas a la búsqueda y exploración de este mineral (MANRIQUE, 2014, p.23). A la ya madura explotación del Salar del Hombre Estudos Geográficos, Rio Claro, 15(1): 157-183, jan./jun. 2017 (ISSN 1678-698X) http://www.periodicos.rc.biblioteca.unesp.br/index.php/estgeo 
Muerto en Catamarca -objeto de análisis en este trabajo- deben añadirse los casos del jujeño Salar de Olaroz -en producción desde 2014 a partir de un joint-venture entre la minera australiana Orocobre y la automotriz japonesa Toyota- y del salteño Salar de Olaroz-Cauchari -cuya planta piloto fue inaugurada recientemente por las mineras canadienses Lithium America Corporation y Exar Magma International y la automotriz nipona Mitsubishi-. En los últimos años mineras australianas, canadienses, francesas y estadounidenses asociadas a firmas tecnológicas y automotrices como LG, Posco, Kores y Renault se han abalanzado sobre yacimientos que actualmente se hallan en diferentes etapas de exploración, como Salar del Gualicho (Río Negro), Salinas Grandes (Córdoba), Sal de Vida, Laguna de Guayatavoc, Antofalla, Incahuasi y Oro Blanco-Laguna Verde-Tres Quebradas (Catamarca), Rincón, Pocitos y Arizaro (Salta) y Salinas Grandes y Jama (Jujuy).

Si bien Argentina es el país con menores reservas del 'triángulo del litio', la creciente afluencia de firmas extranjeras interesadas en este mineral obedecería, en principio, a factores geológico-climáticos, tales como los altos niveles de concentración del litio -por encima de las 500 ppm-, la gran aridez de la puna -que aumenta la tasa de evaporación, reduciendo así los tiempos y costos de la extracción-, la vasta superficie de los salares y su excepcional calidad -debido a la abundancia de potasio (que aumenta el margen de ganancias de las empresas) y la escasez de magnesio (que incrementa los costos de producción, dificultando la recuperación del litio y demandando mayores cantidades de insumos)-. No obstante, otro factor clave es el hecho que la Argentina es el único país del triángulo del litio donde este mineral es concesible el capital privado, a diferencia de Bolivia -donde la explotación del recurso es potestad del Estado nacional- y Chile -cuya Constitución Nacional prohibió a partir de 1982 efectuar nuevas concesiones-.

\section{MINERÍA DEL LITIO Y ACUMULACIÓN POR DESPOSESIÓN. EL CASO DE SALAR DEL HOMBRE MUERTO (1999-2016)}

\section{LA EXPROPIACIÓN GEOGRÁFICA: ENCLAVES EXPORTADORES, PRIVATIZACIÓN, EXTRANJERIZACIÓN Y DESARROLLO}

Localizado en el norte de la provincia de Catamarca, concretamente en el departamento de Antofagasta de la Sierra (Mapas 1 y 2), el Salar del Hombre Muerto es uno de los más ricos e importantes yacimientos de litio no sólo de nuestro país, sino del mundo. Emplazado a una altitud que oscila entre los 3.400 y los 4.600 metros sobre el nivel del mar, en un área de clima riguroso, gran estacionalidad, extrema aridez -precipitaciones de $150 \mathrm{~mm}$ anuales- y gran amplitud térmica diaria temperaturas mínimas de $-^{\circ}$ $\mathrm{C}$ y máximas de $32^{\circ} \mathrm{C}$-, este salar es el mayor reservorio de litio del planeta después de Uyuni (Bolivia), Atacama (Chile), Rincón (Argentina), Taijanair y Zhabuye (China). Si bien es relativamente pequeño, este yacimiento contiene litio a mucha mayor profundidad (70 metros) y en concentraciones mucho más uniformes que las registradas en formaciones similares del noroeste argentino. Con recursos que ascienden a las 850.000 toneladas (REDAJ, 2011, p. 3; ARÉVALO MOSCHELLA, 2015, p. 4), la concentración promedio del mineral es de 692 ppm, guarismo que lo sitúa por encima de la mayoría de los yacimientos actualmente en explotación, a excepción de Atacama y Zhabuye. Otras condiciones naturales que lo jerarquizan son su elevada tasa de

Estudos Geográficos, Rio Claro, 15(1): 157-183, jan./jun. 2017 (ISSN 1678-698X)

http://www.periodicos.rc.biblioteca.unesp.br/index.php/estgeo 
evaporación (2.775 mm/año) -sólo superada por el Salar de Atacama y el Clayton Valley (Estados Unidos)- (ZíCARI, 2015, p. 21), así como también la escasa presencia de impurezas, plasmada sobre todo en un excepcionalmente bajo radio magnesio/litio (1.37/1) que abarata el proceso extractivo (SEVARES y KRZEMIEN, 2012, p. 137).

Mapas 1 y 2. República Argentina, según división político-territorial (provincias). Localización de la mina Salar del Hombre Muerto y las plantas de carbonato y cloruro de litio de Minera del Altiplano
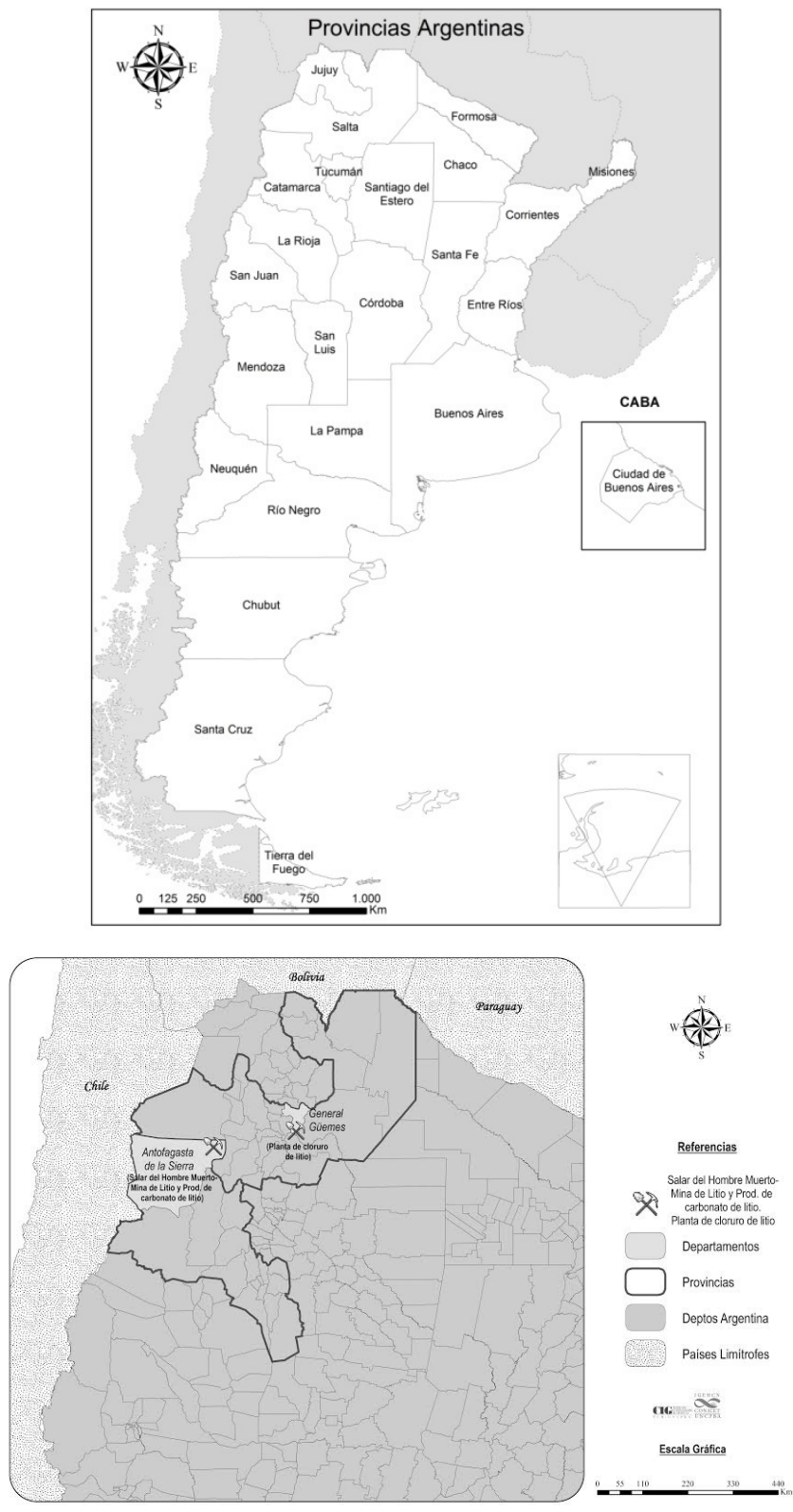

Fuente: elaboración personal.

Luego de las fallidas negociaciones políticas y los álgidos conflictos sociales que impidieron la explotación del Salar de Uyuni en Bolivia, y afectada por las denuncias de contaminación ambiental en la ciudad estadounidense de Bassemer 
(NACIF, 2014, s/p), la minera norteamericana FMC Lithium ${ }^{5}$ y su subsidiaria argentina Minera del Altiplano S.A. procuraron reactivar el abandonado proyecto de extracción de litio en Salar del Hombre Muerto. Orientadas a satisfacer las exigencias del capitalismo estadounidense y el llamado Consenso de Washington las reformas estructurales neoliberales implementadas a comienzos de la década de 1990 -liberalización comercial y financiera, privatización masiva de empresas públicas, meteórico endeudamiento externo, apertura importadora, desregulación económica, apertura indiscriminada al capital foráneo, retraso cambiario, flexibilización laboral, retirada del Estado de la vida socioeconómica, reprimarización del aparato productivo, etc.- indudablemente allanaron el camino para los intereses de la minera extranjera.

En ese contexto, FMC Lithium y Minera del Altiplano suscribieron con la Dirección Provincial de Fabricaciones Militares (DPFM) un contrato que, en principio, contemplaba la exploración y desarrollo conjunto del proyecto, pero que a partir de 1995 -luego de que DPFM fuera liquidada por el Estado nacional- derivó en la cesión total de los derechos de explotación a la compañía estadounidense. La concesión del sexto reservorio de litio del mundo a la FMC Lithium y su subsidiaria fue, de hecho, el primer episodio de acumulación por desposesión asociado a la minería metalífera en la Argentina: la privatización de tierras públicas y la apropiación neocolonial e imperial de los bienes comunes del subsuelo y el patrimonio geológico para su posterior conversión en recursos estratégicos para la producción de commodities bajo la propiedad privada del capital foráneo. Años más tarde, Minera del Altiplano ampliaría ese proceso de cercamiento territorial al adueñarse de 100.000 hectáreas de tierras fiscales cercanas a Salar del Hombre Muerto para especular con los pedimentos mineros allí solicitados (EL ESQUIÚ, 2012a, s/p).

Bajo el nombre de 'proyecto Fénix', la extracción de litio en Salar del Hombre Muerto comenzó en 1999, luego de que FMC invirtiera 137 millones de dólares en tareas de exploración, prospección, construcción y puesta en operación de la mina y sus instalaciones industriales (MAPA CONFLICTOS MINEROS, 2017, s/p). Como resultado, la empresa diseñó un circuito productivo propio, basado en dos complejos extractivo-industriales, uno ubicado en el propio yacimiento -compuesto por la planta de absorción selectiva para remover el litio de la salmuera natural, la planta de servicios auxiliares (abastecimiento de electricidad, vapor y aire comprimido) y la planta de producción de carbonato de litio-, y otro localizado en la provincia de Salta -constituido por la planta procesadora de cloruro de litio (departamento de General Güemes) y la estación ferroviaria de cargas (Salar de Pocitos)- (FARN-CEDIB, 2014, p. 20). Posteriormente, la empresa realizó inversiones adicionales, orientadas a diversificar su base comercial a partir de la producción de compuestos de creciente demanda como el hidróxido y el fluoruro de litio y de fertilizantes como el cloruro de potasio (49 millones), y extender en $145 \mathrm{~km}$ la traza del Gasoducto de la Puna para evitar así el traslado de gas natural en camiones entre el yacimiento y sus plantas industriales (110 millones de dólares) (EL ESQUIÚ, 2012b, s/p).

Según diversas fuentes, la producción anual de FMC a partir del mineral extraído en Salar del Hombre Muerto se estima en 12.000 toneladas de carbonato de litio y entre 6.000 y 20.000 toneladas de cloruro de litio (FARN-CEDIB, 2014, p. 20; SEVARES y KRZEMIEN, 2012, p. 137) destinadas en su totalidad a los mercados internacionales. Si bien la minería metalífera representa casi el $95 \%$ de

\footnotetext{
${ }^{5}$ Con sede en Chicago, la compañía norteamericana opera 107 minas y plantas industriales en 25 países. En 2012 se fusionó con la minera australiana Galaxy Resources, asociada a su vez a un consorcio de empresas surcoreanas.

Estudos Geográficos, Rio Claro, 15(1): 157-183, jan./jun. 2017 (ISSN 1678-698X)

http://www.periodicos.rc.biblioteca.unesp.br/index.php/estgeo
} 
las exportaciones catamarqueñas, esto no obedece a la dinámica de Salar del Hombre Muerto, sino al enorme peso relativo del cobre y el oro extraído en el megayacimiento Bajo La Alumbrera; de hecho, durante el período 2008-2014 las exportaciones de carbonato de litio oscilaron entre los 35.500 .000 y los 46.200 .000 dólares anuales -esto es, entre el $2,4 \%$ y el 3,7\% del comercio exterior catamarqueño-, mientras que en igual período las remesas de cloruro de litio fueron más erráticas, fluctuando entre 16.000 .000 y los 33.600 .000 dólares/año -es decir, el $2,8 \%$ de las exportaciones salteñas (MECON, 2013, s/p; CAC, 2015, s/p).

Superponiéndose al tejido socio-productivo preexistente de los espacios locales, la dinámica de acumulación corporativa diseña su propia geometría espacial de flujos y puntos valorizados -esto es, sus "circuitos espaciales de producción" y sus "círculos de cooperación en el espacio" (MORAES, 1988, p. 156)- y construyendo así lo que Silveira (1999, p. 187) llama el "territorio de las verticalidades". La minería transnacional del litio no es una excepción a esa regla; al contrario, produce una suerte de "expropiación geográfica" (MACHADO ARÁOZ, 2011, p. 166-167) basada en la implantación de economías de enclave que insertan a los lugares en el mercado mundial pero que al mismo tiempo los alienan de su entorno inmediato.

Luego de sufrir un procesamiento elemental para su conversión en carbonato de litio, una parte del mineral extraído de Salar del Hombre Muerto es exportada, en tanto que el resto es remesado a la planta salteña de General Güemes para la obtención de cloruro de litio (Mapa 2). En ambos casos, la producción es embarcada en Pocitos (Salta) y transportada por ferrocarril hasta el puerto chileno de Antofagasta, desde donde es exportada. Procurando usufructuar las ventajas logísticas otorgadas por el Tratado Argentino-Chileno de Integración Minera, la minera estadounidense procura reducir sus costos operativos aprovechando la infraestructura disponible y el empalme de los ramales del Belgrano Cargas (Argentina) y Ferronor (Chile) para evitar la necesidad de trasbordo y exportando a través del Océano Pacífico -más accesible a los principales países importadores de litio- en vez de atravesar gran parte del país para comercializar su producción vía los puertos argentinos a orillas del Atlántico. Dado que el citado tratado minero bilateral independizó por cuarenta años a la Cordillera de los Andes de la jurisdicción de los respectivos gobiernos nacionales, esta singular división territorial del trabajo obedece también al hecho de que en los territorios involucrados no existe control aduanero ni fiscal alguno, situación que, en virtud de su condición de zona franca, es compartida por la localidad salteña de General Güemes. Surge así una geografía formada por áreas de alta densidad normativa (SILVEIRA, 1997, p. 43) donde las leyes que operan y rigen no son las de los Estados nacionales, sino las del mercado mundial.

Después de Chile, la Argentina es actualmente el segundo exportador mundial de litio, acaparando el $19,8 \%$ de las ventas externas de ese mineral. Los principales destinos del litio argentino son Japón (42,6\%), Estados Unidos $(35,8 \%)^{6}$ y, en menor medida, Corea del Sur, Bélgica y China. En 2016, esos cinco países se apropiaban del $98,7 \%$ de las remesas nacionales de dicho producto (TRADEMAP, $2017, \mathrm{~s} / \mathrm{p}$ ), el cual a su vez satisfacía el $40 \%$ del consumo norteamericano (REDAJ, 2011, p. 5).

\footnotetext{
${ }^{6}$ Paulatinamente, Japón ha reemplazado a Estados Unidos como destino principal del litio argentino: en 2001, ambos países daban cuenta del $91,7 \%$ y el $8,3 \%$; en 2016 , su participación se situaba en el orden del $35,8 \%$ y el 42,6\%, respectivamente (TRADEMAP, 2017, s/p).

Estudos Geográficos, Rio Claro, 15(1): 157-183, jan./jun. 2017 (ISSN 1678-698X)

http://www.periodicos.rc.biblioteca.unesp.br/index.php/estgeo
} 
Como uso extractivo del territorio, la minería del litio revela ciertamente una división internacional del trabajo fundada en el intercambio desigual de materias primas y productos industrializados entre, por un lado, los países periféricos y, por el otro, las grandes potencias y sus economías-satélite. En 2012, el valor de mercado del carbonato de litio ascendía, en promedio, a 6.000 dólares por tonelada, pero la cotización internacional del litio metálico superaba los 6.000 dólares por kilogramo; paralelamente, el costo de las baterías para automóviles eléctricos e híbridos -que cuentan con apenas 10 kilogramos de carbonato de litio- oscilaba entre 10.000 y 20.000 dólares (La Nación, 2012, citado por MANRIQUE, 2014, p. 30-31). A pesar de contar con un subsuelo rico en ese mineral, Argentina no ha desarrollado políticas de industrialización que le permitan autoabastecerse de pilas y baterías de litio y acumuladores Li-Ion; por el contrario, importa estos productos de alto valor agregado desde Tailandia, Estados Unidos, China, Corea del Sur, Indonesia, Japón, Inglaterra, Canadá, Francia y Singapur (TRADEMAP, 2017, s/p), adquiriendo el $45,1 \%$ de las pilas/baterías y el $95,9 \%$ de los acumuladores a los países que son destinatarios de sus exportaciones de la materia prima o bien re-exportan los bienes electrónicos fabricados por estos últimos. Combinada con la ausencia de encadenamientos productivos significativos a escala regional y nacional, esta situación determina que tanto Salar del Hombre Muerto como General Güemes funcionen como meros enclaves exportadores técnica y políticamente subordinados a las cadenas mundiales de valor verticalmente organizadas del capital extranjero globalizado.

Asimismo, otro rasgo propio de la minería metálica de exportación son los llamados 'nuevos cercamientos', una dinámica expropiatoria que, arquetípica o secular desarrollada ininterrumpidamente a lo largo de toda la historia del capitalismo, es una de las piedras angulares sobre las cuales se sustenta actualmente el enfoque de la acumulación por desposesión. En 2005, pobladores catamarqueños denunciaron que Minera del Altiplano había instalado un vallado metálico perimetral que, emplazado en tierras fiscales provinciales, impedía el paso de alumnos escolares, campesinos de la zona y turistas por la única huella transitable existente entre la Escuela del Salar del Hombre Muerto, la villa de Antofagasta de la Sierra y la ruta provincial № 43. Ante la mirada cómplice del Estado, la empresa cercenaba así los derechos de libre transitabilidad por el territorio nacional garantizados por la Constitución Nacional y la Constitución de la Provincia de Catamarca, dado que sólo permitía la apertura del vallado y la circulación de los pobladores una vez que éstos esperaran a ser atendidos, indagados y requisados por personal de la firma (El Ancasti, 2005), arrogándose así atribuciones similares a las fuerzas públicas de seguridad.

Otro hito que da aún más pábulo a la tesis de una expropiación geográfica basada en economías de enclave es que la dinámica de acumulación de este modelo de extracción y exportación de recursos estratégicos no renovables no ha contribuido en absoluto al desarrollo socioeconómico del departamento de Antofagasta de la Sierra. La minería transnacional del litio, de hecho, erosiona la coherencia interna de un área arquetípicamente caracterizada por la presencia de población con fuerte componente campesino y aborigen (descendiente de la etnia diaguita) que practica una economía familiar de subsistencia basada en la ganadería -principalmente caprinos, ovinos y camélidos auquénidos como llamas y vicuñas), la agricultura minifundista -maíz, trigo, papas, habas, quinoa, cebolla-, las artesanías textiles y la extracción de sal. Si bien ciertas características histórico-naturales aridez, relieve montañoso, matriz económica frágil y endeble, escasa aptitud agroEstudos Geográficos, Rio Claro, 15(1): 157-183, jan./jun. 2017 (ISSN 1678-698X) http://www.periodicos.rc.biblioteca.unesp.br/index.php/estgeo 
ecológica para cultivos dinámicos, etc.- han obrado, junto al estigma de 'provincia pobre' y la metáfora del 'desierto de piedra', como pretextos para la implantación en Catamarca del modelo metalífero (SVAMPA et al., 2009, p. 41), los 1.430 habitantes de Antofagasta de la Sierra continúan tan ajenos a la modernidad -y al presunto 'efecto-derrame' del boom minero- como lo estaban antes de la llegada de la FMC Lithium.

Ejemplo de ello es, ciertamente, el escaso empleo directo generado por la explotación de Salar del Hombre Muerto. Diversas fuentes coinciden en que la creación de empleo vinculada a la minera estadounidense es irrelevante: la etapa de construcción del yacimiento demandó aproximadamente 600 trabajadores (REDAJ, 2011 , p. 9), pero actualmente su plantilla de personal sólo está conformada por entre 240 y 289 obreros, distribuidos entre las plantas productivas de Antofagasta de la Sierra y General Güemes (REDAJ, 2011, p. 9; EL ESQUIÚ, 2012b, s/p). En términos generales -esto es, sin discriminar entre sus distintas ramas (rocas de aplicación y construcción, minerales energéticos y metales)-, el sector minero representaba en 2010 apenas el 0,22\% del empleo registrado en Antofagasta de la Sierra (INDEC, $2013, \mathrm{~s} / \mathrm{p}$ ). Al derivarse de datos agregados, estos guarismos sobredimensionan a su vez el impacto real del sub-sector metalífero sobre el mercado de trabajo local.

Por añadidura, el origen geográfico de la inmensa mayoría de los obreros contratados no es local, ni siquiera provincial. Según datos emanados de diferentes fuentes (EL ESQUIÚ, 2012a, s/p; 2012b, s/p; TAPIA, QUIROGA y SÁNCHEZ, 2015, p. 50), entre 6 y 23 personas son oriundas de esa provincia, cifra que representaría apenas entre el $2 \%$ y el $8 \%$ de la plantilla laboral global. En virtud del absoluto predominio de prácticas de tercerización laboral, el empleo creado evidencia asimismo fuertes niveles de precarización; de hecho, la inmensa mayoría de los trabajadores no tiene relación directa con Minera del Altiplano, sino a través de una consultora llamada ADECO (EL ESQUIÚ, 2012a, s/p). Finalmente, las huelgas obreras y los conflictos sindicales son frecuentes debido a las magras remuneraciones pagadas por la firma extranjera a su personal (NALM, 2012, s/p).

Lejos de erigirse en un factor de enraizamiento territorial para la población, el auge de la minería del litio tampoco ha detenido la dinámica de expulsión demográfica que típicamente ha caracterizado a Antofagasta de la Sierra; de hecho, la migración es un fenómeno preocupante para el gobierno local, dado que aproximadamente el $18 \%$ de la población oriunda de ese departamento ha desplazado su lugar de residencia hacia la capital provincial (San Fernando del Valle de Catamarca), proceso protagonizado sobre todo por jóvenes que buscan mejores condiciones de vida y oportunidades laborales (TAPIA, QUIROGA y SÁNCHEZ, 2015, p. 49).

Aunque los voceros y defensores del modelo hegemónico se empeñen en sostener exactamente lo contrario, el boom del litio no ha conducido a la superación de la pobreza y la precarización laboral. Con respecto a la pobreza estructural, en Antofagasta de la Sierra la tasa de hogares con Necesidades Básicas Insatisfecha ascendía en 2010 al 17,5\%, frente a un promedio nacional y provincial del $9,1 \%$ y el $11,3 \%$, respectivamente; este guarismo convertía a Antofagasta de la Sierra en el cuarto departamento catamarqueño con mayores niveles de pobreza estructural (DINREP, 2014, p. 25). Sobre un universo de 510 departamentos que componen el territorio argentino, este departamento se situaba en el $387^{\circ}$ puesto, en el segundo peor quintil del conjunto general. Asimismo, más de la tercera parte de la población local $(37,9 \%)$ no contaba con cobertura de salud, según datos del último Censo Nacional de Población, Hogares y Viviendas realizado en 2010 (INDEC, 2013, s/p).

Estudos Geográficos, Rio Claro, 15(1): 157-183, jan./jun. 2017 (ISSN 1678-698X)

http://www.periodicos.rc.biblioteca.unesp.br/index.php/estgeo 
Información oficial proporcionada por esa misma fuente incluso señalaba que más de la mitad de los hogares $(59,2 \%)$ poseía una conexión a los servicios básicos de calidad insuficiente, y que nada menos que el $97,8 \%$ de la población local residía en viviendas de construcción deficiente (INDEC, 2013, s/p). En resumidas cuentas, estos indicadores sociales se encuentran evidentemente muy por debajo de lo esperable para una jurisdicción que -al menos según los promotores y/o defensores de la minería metalífera- ha sido pródiga 'beneficiaria' de las 'bondades' del modelo. Otra cuestión a subrayar es la magra contribución de la minería metalífera el erario público. Conforme a la legislación vigente, las empresas deben pagar regalías a las provincias donde se emplazan los yacimientos explotados, abonando hasta un monto máximo del 3\% del valor bruto de producción en boca de mina. Impulsado por Bajo La Alumbrera y Salar del Hombre Muerto, el boom metalífero catamarqueño no ha puesto fin, empero, a la histórica dependencia provincial respecto de las remesas de aportes desde el Estado nacional; de hecho, más del $80 \%$ de sus recursos tributarios procede de los ingresos por coparticipación federal, al menos 30 veces más grandes que las regalías mineras (NALM, 2014, s/p).

Según la normativa catamarqueña, entre el $35 \%$ y el $50 \%$ del monto recaudado por regalías mineras debe ser asignado al departamento donde se localiza el yacimiento bajo explotación. Recibiendo unos 2 millones de pesos anuales por tal concepto (NALM, 2012, s/p), Antofagasta de la Sierra es justamente el distrito que mayor cantidad de ingresos percibe a partir de la redistribución de la masa de recursos tributada por la explotación de Salar del Hombre Muerto (TAPIA, QUIROGA y SÁNCHEZ, 2015, p. 49). Recientemente, el departamento recibió 1.379.486 pesos correspondientes a la liquidación de las regalías del primer trimestre de 2016 (EL ESQUIÚ, 2017, s/p), cifra que, extrapolada a la totalidad del ciclo anual, se hallaría en el orden de los 5.500 .000 pesos. Como resultado, Antofagasta de la Sierra recibe menos de 400.000 dólares al año por la explotación del sexto yacimiento de litio del mundo, una cifra que representa apenas el $0,14 \%$ de la facturación anual de Minera del Altiplano -más de 260 millones de dólares en 2011 (EL ESQUIÚ, 2012c, s/p)-.

Otra problemática surgida a partir de la eclosión y desarrollo de la minería del litio en la Puna argentina -y estrechamente relacionada con lo anterior- ha sido la reedición de antiguos conflictos políticos regionales, que han enfrentado en más de una ocasión a Catamarca y Salta. En 2007, Minera del Altiplano expandió la explotación de Salar del Hombre Muerto hacia el norte catamarqueño, en la frontera con Salta, área históricamente disputada por ambas provincias debido a un antiguo y todavía irresuelto diferendo limítrofe. A raíz de esta suerte de labilidad territorial, los derechos de concesión de las nuevas áreas de extracción de la FMC Lithium fueron otorgados por un juez de minas salteño, hecho que el gobierno catamarqueño interpretó como una violación de sus derechos político-administrativos al punto de instalar dos destacamentos policiales en la zona en disputa. A su vez, en 2012 el Juzgado de Minas y la Corte Suprema de Justicia de Salta intervinieron exigiéndole a Minera del Altiplano que tributara a esa provincia regalías por la explotación de las nuevas áreas concedidas, demanda que fue rechazada por la empresa transnacional argumentando que el Salar del Hombre Muerto es una unidad geológica y que los tribunales involucrados eran incompetentes para expedirse sobre límites interprovinciales ${ }^{7}$ (CONTACTO MINERO, 2012, s/p; NACIF, 2014, s/p).

\footnotetext{
${ }^{7}$ Sin embargo, la empresa había solicitado la concesión de las minas a Salta, donde además ya contaba -amén de sus plantas industriales y la estación ferroviaria- con caminos de servidumbre de paso.

Estudos Geográficos, Rio Claro, 15(1): 157-183, jan./jun. 2017 (ISSN 1678—698X)

http://www.periodicos.rc.biblioteca.unesp.br/index.php/estgeo
} 
Si bien el conflicto ya superó su etapa más álgida, aún permanece irresuelto, demostrando que la minería metálica transnacional, lejos de operar como un factor de integración regional, ha reavivado antagonismos pretéritos que incitan a los espacios involucrados a disputarse las migajas dejadas por el modelo extractivista.

Finalmente, la falacia del desarrollo local asociado a la minería transnacional del litio queda expuesta al corroborar la frágil (y prácticamente inexistente) articulación de Minera del Altiplano al tejido socio-productivo de Antofagasta y su área de influencia; resulta difícil dar crédito a la afirmación de que la firma trabaja mayormente con proveedores locales (EL ESQUIÚ, 2015a, s/p) cuando se advierte que el departamento carece de servicios comerciales básicos -sucursales bancarias, estaciones de expendio de combustible, talleres mecánicos, ferreterías- y servicios profesionales permanentes (TAPIA, QUIROGA y SÁNCHEZ, 2015, p. 51).

Paralelamente, la minera estadounidense desarrolla programas de Responsabilidad Social Empresaria que incluyen la asistencia a comedores infantiles y comunitarios, las donaciones a hospitales públicos (equipamiento, insumos médicos y materiales) y los programas de becas coordinados con las universidades nacionales de Salta y Catamarca (EL ESQUIÚ, 2012a, s/p). Teorizando acerca de los mecanismos de la economía política de la dominación desplegados por las empresas mineras en Catamarca, Machado Aráoz (2013b, p. 24 y 28-30) sostiene que estas sofisticadas tecnologías de marketing social obedecen a la necesidad del poder (neo)colonial de que la población se identifique con el modelo hegemónico; convertida en el nuevo agente colonizador, la corporación minera transnacional opera como un Estado paralelo que se ocupa personalmente de todo -educación, salud, asistencia- para inocular en el imaginario colectivo la contaminación social y moral necesaria para completar el saqueo y la expropiación, poner en funcionamiento la maquinaria clientelar e instalar las formas de pensar, sentir y actuar acordes con los requisitos para acceder al desarrollo. Mientras tanto, Antofagasta de la Sierra carece en pleno Siglo XXI de energía eléctrica, red de agua potable, provisión de gas natural, alcantarillado, red telefónica -a excepción de una antena de telefonía celular- y transporte público que conecte a todos los distritos del ejido municipal, lo cual dificulta la escolaridad y el acceso a la salud primaria. Y como resultado de la inexistencia de bioquímicos y especialidades médicas, el escaso personal sanitario y la carencia de equipamiento del sistema de asistencia primaria de la salud, la población antofagasteña debe desplazarse hacia nosocomios públicos y privados de mediana o alta complejidad localizados en la capital provincial (TAPIA, QUIROGA y SÁNCHEZ, 2015, p. 61).

\section{NORMAS, CONTAMINACIÓN AMBIENTAL Y RECURSOS HÍDRICOS: LAS DINÁMICAS ECONÓMICO-POLÍTICAS Y SOCIO-ECOLÓGICAS DEL SAQUEO}

Operando como creadoras de territorio, las normas producen y transforman el orden social y espacial a través de políticas y comportamientos (SILVEIRA, 2000, p.121). Como resultado, los lugares pasan a distinguirse en virtud de su productividad espacial, esto es, a partir de su capacidad diferencial de ofrecer rentabilidad a las inversiones en función de determinadas condiciones técnicas (equipamientos, infraestructura, accesibilidad) y organizacionales (leyes, impuestos, etc.) que, superponiéndose a las virtualidades naturales locales, favorecen la acumulación capitalista en general y, particularmente, la producción de un

Estudos Geográficos, Rio Claro, 15(1): 157-183, jan./jun. 2017 (ISSN 1678—698X)

http://www.periodicos.rc.biblioteca.unesp.br/index.php/estgeo 
determinado bien (SANTOS, 1996, p. 197-199). Orientadas a moldear las regulaciones jurídicas, organizacionales y financieras domésticas en función de las exigencias de un mandar hegemónico global (SILVEIRA, 2000, p. 211), esas políticas y comportamientos buscan activar la producción de dispositivos expropiatorios que, sobre la base de reformas normativo-institucionales, recompongan la tasa de ganancia empresarial. Para Machado Aráoz (2011, p. 167168), esto genera una expropiación económica y una producción política de rentabilidad que, en tanto formas de acumulación por desposesión, generan una descomunal transferencia de recursos hacia los centros mundiales de poder. Contemplando diversos mecanismos, este proceso opera en varias escalas, desde la nacional hasta la local.

La minería metalífera en la Argentina es un ejemplo paradigmático de las dimensiones político-económicas del saqueo construidas a partir de la puesta en práctica de determinadas reformas normativo-institucionales. Auxiliado por créditos del Banco Mundial, el gobierno nacional diseñó durante el sexenio 1993-1998 un andamiaje jurídico extremadamente favorable para el desarrollo y expansión de la actividad, el cual incluyó normas tales como la Ley de Inversiones Mineras, el nuevo Código de Minería, la Ley de Reordenamiento Minero, el Acuerdo Federal Minero y el previamente citado Tratado de Integración Minera con Chile. La nueva legislación desde entonces contempla un inaudito espectro de ventajas fiscales, arancelarias, tributarias, comerciales, financieras, políticas y territoriales, tales como la estabilidad fiscal por 30 años, la desgravación de las importaciones de insumos y bienes de capital (arancel 0\%), el reembolso del Impuesto al Valor Agregado (IVA), la doble deducción de costos de exploración, el pago de un módico canon por los derechos de concesión de los yacimientos -apenas 800 pesos mensuales para las minas de primera categoría (ZíCARI, 2015, p.35)- y de las ya mencionadas regalías provinciales -con un tope máximo del 3\% del valor bruto en boca de mina-, la eliminación de gravámenes y tasas municipales, y la exención del Impuesto al Cheque, a los Sellos, a los Combustibles y a la Ganancia Mínima Presunta.

Luego del fin del Régimen de Convertibilidad -basado en la paridad nominal entre el peso argentino y el dólar estadounidense durante el período 1991-2001-, la mega-minería resultó fuertemente beneficiada por la reducción de los costos de producción ocasionada por la devaluación en 2002 de la moneda nacional, sin la retención de parte del excedente por ella creado (NACIF, 2014, s/p). Recién en 2007 el gobierno nacional intentó cobrar al sector derechos de exportación, pero las mineras extranjeras ensayaron una enconada resistencia, en algunos casos pagando bajo protesto y en otros interponiendo medidas cautelares que argüían que esa política violaba la estabilidad fiscal de sus inversiones. Posteriormente, otras ventajas adicionales ofrecidas por el Estado incluirían permisos para exportar y remitir utilidades al exterior sin pagar impuestos y utilizar cuentas off shore como base para activos financieros y plazas de depósito para divisas, la exención del IVA y el Impuesto a Créditos y Débitos Bancarios, la deducción del Impuesto a las Ganancias, el financiamiento del Programa de Gestión Ambiental Minera y, a partir de 2016, la definitiva eliminación de las retenciones a las exportaciones.

El apoyo incondicional a la minería metálica de exportación se ha convertido en una indiscutible política de Estado, tal como lo demuestra la creación de la Organización Federal de Estados Mineros (OFEMI) -que aglutina a las provincias de Jujuy, Salta, Catamarca, San Juan, Mendoza, Neuquén, Río Negro, Chubut y Santa Cruz- y el ascenso de la otrora Dirección de Minería al rango secretarial primero y ministerial después. Otros mecanismos instrumentados desde el poder político han

Estudos Geográficos, Rio Claro, 15(1): 157-183, jan./jun. 2017 (ISSN 1678—698X)

http://www.periodicos.rc.biblioteca.unesp.br/index.php/estgeo 
generado ingentes beneficios económicos para las mineras extranjeras. Las millonarias inversiones en capital requeridas para la puesta en explotación de los yacimientos son externalizadas al Estado, quien asume la responsabilidad por mejorar caminos y puentes, ceder tierras fiscales, expropiar tierras privadas, realizar obras de adaptación de la red hídrica, energética y vial, y garantizar un ilimitado abastecimiento de gas y electricidad -tendido de líneas de alta tensión (500 KV), entrega de energía a precio subsidiado-. Subsidios y reintegros comerciales y fiscales suprimen e incluso revierten los costos de producción de las empresas.

Obstando el alcance general de estas reformas políticas -usufructuadas en mayor o menor medida por todos los concesionarios de las minas actualmente en explotación en el país-, el caso de Salar del Hombre Muerto merece particular atención. A diferencia de Chile -donde la ley reconoce a este mineral como un recurso estratégico e impone límites para su extracción- y Bolivia -donde se lo considera prioridad nacional-, el litio carece en Argentina de una regulación especial, aplicándosele por tanto el permisivo y laxo régimen común que rige para el resto de los minerales metalíferos. A los ya comentados privilegios fiscales y tributarios vigentes a escala nacional se le añade, además, el régimen promocional vigente en Catamarca, que exime del pago de impuestos provinciales por un plazo de quince años a todas aquellas empresas que ocupen a más de 50 personas y/o utilicen el $40 \%$ de materia prima local (ANDRADA, 2002, s/p). Asimismo, y en virtud del reintegro adicional del 5\% a las exportaciones mineras de Catamarca, Salta y Jujuy dispuesto por el Estado nacional a partir de 1993, Minera del Altiplano se apropia de una considerable masa de recursos públicos debido a los reintegros otorgados a la comercialización de litio metálico y cloruro de litio $(5 \%)$, hidróxido de litio $(8,5 \%)$ y carbonato de litio $(10,5 \%)$ (NACIF, 2014, s/p). No conforme con estas generosas e inauditas ventajas fiscales y comerciales, en 2011 la minera estadounidense inició acciones legales contra el gobierno nacional, negándose a cumplir con la norma que la obligaba a tributar el canon minero de Salar del Hombre Muerto no sólo a Catamarca, sino también a Salta (FARN-CEDIB, 2014, p. 21) ${ }^{8}$.

Otra forma de producción política de rentabilidad atañe a las obras públicas de infraestructura energética, plasmadas en el acceso privilegiado de Minera del Altiplano al abastecimiento de gas derivado del tendido del Gasoducto de la Puna. Orientada exclusivamente a permitir la expansión de las operaciones extractivas de Salar del Hombre Muerto, la construcción de los primeros tramos del Gasoducto de la Puna en 2007 fue licitada y financiada por el Estado nacional, quien aprovechó infraestructura preexistente -el Gasoducto Atacama, que exportaba gas a Chile- para impulsar la obra. Dado que el Acuerdo Federal Minero conmina a las provincias a evitar 'distorsiones' en las tarifas de energía y otros servicios a las empresas (MACHADO ARÁOZ et al., 2011, p. 55), el consumo de gas natural de FMC Lithium entre 75.000 y 90.000 metros cúbicos diarios (NALM, 2013, s/p; EL ESQUIÚ, 2015a, $\mathrm{s} / \mathrm{p}$ )- es facturado a precio diferencial y se encuentra exento de eventuales actualizaciones, indexaciones y modificaciones del cuadro tarifario.

Ocasionada por la degradación del patrimonio ambiental y la depredación de los bienes comunes, la desapropiación socio-ecológica es la última dimensión de la acumulación por desposesión a considerar en este estudio de caso. En un contexto donde la mercantilización de la naturaleza en todas sus formas ha provocado la merma de los bienes hasta ahora comunes del entorno global (tierra, agua, aire) y

\footnotetext{
${ }^{8}$ Agotadas todas las instancias intermedias, el conflicto debió ser resuelto por la Corte Suprema de Justicia de la Nación, quien falló a favor del Estado nacional y obligó a la empresa a tributar el canon en ambas provincias. Estudos Geográficos, Rio Claro, 15(1): 157-183, jan./jun. 2017 (ISSN 1678-698X) http://www.periodicos.rc.biblioteca.unesp.br/index.php/estgeo
} 
un creciente deterioro del hábitat (HARVEY, 2004, p. 118), la minería metalífera ha sido recurrentemente sindicada -tanto en América Latina como en la Argentinacomo responsable por la destrucción del paisaje, la pérdida de biodiversidad, la polución atmosférica, la alteración del ciclo hidrológico, la competencia por el uso del recurso hídrico, la contaminación del suelo y el agua con cianuro, metales pesados y drenajes ácidos de roca, y la afectación de la salud de la población.

Si bien el impacto ambiental por contaminación de la minería del litio en general -y de Salar del Hombre Muerto en particular- es considerablemente menor que el otras minas metálicas argentinas -donde se extrae cobre, oro, plata, plomo, zinc y molibdeno a cielo abierto (open pit), o bien combinando esta modalidad de extracción con la explotación subterránea-, Minera del Altiplano ha sido señalada como protagonista de episodios puntuales de dinámicas de expropiación socioecológica ligadas a la polución y degradación del hábitat. Vecinos de Antofagasta de la Sierra han denunciado reiteradamente la contaminación por vertido de residuos plásticos del área comprendida entre el yacimiento y el río Los Patos -situado a 30 km de la mina- y la consecuente alteración de la frágil dinámica ecológica del salar (LA UNIÓN DIGITAL, 2014, s/p). Aunque aquí no se utilizan volúmenes masivos de cianuro de sodio, ácido sulfúrico y sales de plomo y zinc, la evaporación y procesamiento del litio extraído en salmuera requiere grandes cantidades de otros productos químicos peligrosos, tales como carbonato, fosfato, hidróxido y oxalato de sodio, además de cal y otras bases, ácidos e hidróxidos; de hecho, FMC Lithium utiliza un promedio de 2.310 toneladas semanales de estos insumos, además de 1.034 metros cúbicos de diesel oil para la generación de electricidad vía grupos electrógenos (REDAJ, 2011, p. 10). En tal sentido, desde hace ya varios años los campesinos de la zona sindican a Minera del Altiplano como responsable de la polución de arroyos cuya agua utilizan para abrevar el ganado, irrigar cultivos y satisfacer su propio consumo (MAPA CONFLICTOS MINEROS, 2017, s/p).

No obstante, es en la privatización y dilapidación a gran escala de los escasos recursos hídricos locales donde la dimensión socio-ecológica del saqueo asociado a la minería transnacional del litio asume su total magnitud. Solapándose y combinándose con los dispositivos y mecanismos propios de las dinámicas expropiatorias geográficas -la apropiación neocolonial e imperial (vía extranjerización) de los bienes comunes- y económico-políticas -la producción de normas que subsidian la acumulación del capital-, la llamada "exportación de agua virtual' (ALLAN, 2003, s/p) no significa otra cosa que el drenaje -vía comercio internacional- de aquellos recursos hídricos que fueron utilizados como insumo para la producción de determinados bienes. Dada la naturaleza hidro-intensiva de la minería metalífera, la sangría de agua virtual representa en sí misma uno de los aspectos más graves (y menos divulgados) de la acumulación por desposesión (MACHADO ARÁOZ, 2011, p. 170-172), toda vez que representa una estrategia imperialista conforme a la cual los países importadores de metales y las naciones de origen de las compañías mineras externalizan costos ambientales y obtienen un significativo ahorro de agua dentro de sus propias fronteras al colocar vastas reservas de agua dulce bajo el control del capital y desarrollar un desmesurado (y a menudo gratuito) consumo hídrico en la periferia del sistema capitalista mundial.

Sin alcanzar los siderales guarismos de la minería del oro y el cobre, la explotación de litio en salmuera representa una grave amenaza para las reservas de agua dulce, debido básicamente a dos factores: la demanda de grandes volúmenes de recursos hídricos; y la necesidad de condiciones climáticas de extrema aridez que proporcionen una alta tasa o índice de evaporación. Este método extractivo Estudos Geográficos, Rio Claro, 15(1): 157-183, jan./jun. 2017 (ISSN 1678-698X) http://www.periodicos.rc.biblioteca.unesp.br/index.php/estgeo 
consiste en perforar la superficie del salar hasta alcanzar la salmuera, bombear el líquido resultante y enviarlo a través de tuberías a grandes piletas cavadas en las salinas, donde se recurre al uso de energía solar para acelerar la evaporación del agua a cielo abierto y obtener la consiguiente concentración del sedimento de sales. Requiriendo entre 12 y 24 meses, este proceso lleva el nivel de concentración del litio en salmuera del $0,22 \%$ al $6 \%$; posteriormente, la precipitación y agregado de reactivos químicos separa al litio del resto de los minerales y compuestos diluidos en la salmuera (calcio, magnesio, potasio, sodio, sulfatos, boratos, etc.) a través de un proceso de lixiviación que aumenta la concentración al 99,1\% para la obtención de carbonato de litio comercial. Esto último también implica un importante consumo hídrico, equivalente al 40\% del agua evaporada (MANRIQUE, 2014, p. 35).

Obstando el hecho de que los estudios de impacto ambiental de las mineras abocadas a la extracción de litio rara vez hacen referencia a la utilización de agua, lo cierto es que todos los estudios de factibilidad realizados por las empresas muestran exhaustivos diagnósticos sobre los recursos hídricos disponibles para sus proyectos (REDAJ, 2011, p. 8). Existe, asimismo, cierto consenso académico al respecto, estimándose que la extracción de una tonelada de litio requiere la evaporación de alrededor de dos millones de litros de agua. Aunque estas cifras varían dependiendo de las características de cada salar y sus diferentes grados de concentración del mineral (ppm), existe contundente evidencia empírica de que este método de explotación no es otra cosa que una 'minería del agua' (GALLARDO, 2011, s/p). El bombeo de volúmenes masivos de agua subterránea no sólo ocasiona un importante descenso del nivel de base de la cuenca (napas y acuíferos), sino que acarrea el descenso del nivel de agua superficial (e incluso el secado) de las lagunas, ríos, arroyos, vegas, vertientes, ciénagas, humedales y ojos de agua que alimentan al salar. La aceleración del flujo de agua subterránea, la consiguiente escasez y/o irreversible desaparición de los escasos recursos hídricos del área y la contaminación (vía salinización) de las capas de agua dulce de las salinas ponen en riego a un ecosistema extremadamente frágil, afectando negativamente a la fauna (camélidos, migraciones de aves) y comprometiendo las economías de subsistencia de comunidades aborígenes y campesinas locales (MANRIQUE, 2014, p. 37).

En este último caso, a la dramática reducción del acceso al vital elemento debe añadirse la contaminación de acuíferos profundos por surgencia de aguas de baja salinidad que, además, arruinan la sal extraída por las cooperativas salineras de la zona (ARANDA, 2011, s/p; AGUILAR y ZELLER, 2012, p. 31-33). Si se considera que, por un lado, las actividades pastoriles y la horticultura constituyen un componente elemental de la supervivencia de estos grupos sociales, y por el otro, la venta o trueque de sal en los mercados regionales representa tanto un complemento básico de estas economías de subsistencia como una práctica inherente a la reproducción de la cultura e identidad andinas (REDAJ, 2011, p.15), es evidente que el desarrollo a gran escala de la minería del litio opera como un mecanismo de acumulación por desposesión que acabará por erosionar o directamente destruir las condiciones materiales e inmateriales de existencia de los agentes subalternos.

De acuerdo a distintas fuentes, el consumo de agua de Minera del Altiplano oscilaría entre 280 y 304 metros cúbicos por hora (REDAJ, 2011, p. 10; EL ESQUIÚ, 2012d, s/p), siendo esta última cifra reconocida por la propia empresa. FMC Lithium cuenta con varias fuentes de aprovisionamiento del recurso, utilizando agua proveniente tanto de fuentes superficiales -cauces de La Punta, río Las Papas- como subterráneas -pozos registrados en la Dirección de Riego y excavaciones no declaradas- (EL ESQUIÚ, 2012d, s/p). En virtud de esta situación, aunada a la Estudos Geográficos, Rio Claro, 15(1): 157-183, jan./jun. 2017 (ISSN 1678-698X) http://www.periodicos.rc.biblioteca.unesp.br/index.php/estgeo 
ausencia de caudalímetros y los laxos controles gubernamentales, no resulta posible constatar la veracidad o confiabilidad de los guarismos argüidos por la minera estadounidense ${ }^{9}$.

Si se consideran como válidas dichas cifras -recordando que la explotación se realiza ininterrumpidamente durante las 24 horas del día-, la extracción de litio en Salar del Hombre Muerto requeriría el consumo de 84,44 litros de agua por segundo, es decir, 7.296.000 litros diarios y 2.663.040 metros cúbicos anuales. Aunque ciertamente este cálculo conservador arrojaría como resultado una huella hídrica sensiblemente inferior a la estimada por los expertos -221.920 litros de agua por tonelada de carbonato de litio, sobre la base de una producción anual de 12.000 toneladas-, estos datos no dejan lugar a dudas acerca del fuerte impacto de la actividad sobre el recurso: aceptando como válido el parámetro de referencia establecido por la Organización Mundial de la Salud (250 litros diarios por persona), la demanda hídrica anual de Minera del Altiplano sería al menos 20,4 veces más grande que el volumen (130.487,5 m3/año) consumido por los 1.430 habitantes del departamento de Antofagasta de la Sierra en idéntico lapso y representaría el 7,93\% del agua utilizada (33.564.305 m3/año) por toda la población de la provincia de Catamarca -367.828 habitantes, según el último Censo Nacional de Población, Hogares y Viviendas realizado en 2010 (INDEC, 2013, s/p)-. Estos guarismos se tornan aún más significativos cuando se advierte que esta dinámica de expoliación de recursos hídricos a gran escala se desarrolla en el sector más desértico del territorio catamarqueño, donde las precipitaciones no superan los $150 \mathrm{~mm}$ anuales.

Obedeciendo al desmesurado consumo del escaso y vital elemento, la remesa al exterior de importantes volúmenes de agua virtual implica un verdadero saqueo en clave de acumulación por desposesión no sólo debido a que la minería del litio supone la privatización y acaparamiento de un recurso escaso -negándoselo a la población local-, sino también en virtud de la impune gratuidad con la que el mismo es apropiado y utilizado. De hecho, y a pesar de los reiterados e infructuosos intentos del gobierno catamarqueño por regularizar tal situación, FMC Lithium se rehúsa a pagar el canon que exige la legislación provincial por el agua consumida en el yacimiento y sus instalaciones industriales, argumentando que entre 1991 y 1994 administraciones anteriores le otorgaron -sin cargo alguno y por lapso indeterminado- la servidumbre y concesión del uso de recursos hídricos para la explotación de Salar del Hombre Muerto. Como resultado, Minera del Altiplano adeuda casi 2 millones de pesos al erario público de Catamarca (EL ESQUIÚ, $2012 d, s / p)$. No obstante, y a pesar tanto del perjuicio ocasionado a campesinos y aborígenes como a la trasgresión de la normativa provincial, el gobierno catamarqueño no dispuso el corte del suministro de agua a la compañía minera estadounidense (EL INVERSOR ON LINE, 2015, s/p), corroborando así una vez más -como sugiere el propio Harvey (2004, p. 118)- que la acumulación por desposesión es un proceso activamente respaldado e incluso fomentado desde distintos segmentos del propio Estado. Recién en 2015 la empresa accedió a compensar a la provincia por el agua que consume, aunque no en términos económicos, sino a través de un fideicomiso para obras de infraestructura cuyo primer destino fue la anteriormente comentada ampliación del Gasoducto de la Puna (EL ESQUIÚ, 2015b, s/p).

\footnotetext{
${ }^{9}$ El caudal de agua utilizado por Minera del Altiplano es desconocido por la Subsecretaría de Recursos Hídricos de Catamarca, a tal punto que en 2006 debió solicitar a la empresa información acerca de su consumo hídrico para poder facturárselo (EL ESQUIÚ, 2012d, s/p).

Estudos Geográficos, Rio Claro, 15(1): 157-183, jan./jun. 2017 (ISSN 1678-698X)

http://www.periodicos.rc.biblioteca.unesp.br/index.php/estgeo
} 
Si bien no se pretende aquí atribuir al agua una representación puramente mercantilista que menoscabe su naturaleza de bien común y derecho humano inalienable a la condición de mero factor de producción, mención aparte merece el exiguo valor económico exigido por el gobierno catamarqueño por el uso de este recurso vital y no renovable. En 2010, la Dirección de Recursos Hídricos intimó a Minera del Altiplano a pagar la irrisoria cifra de 200.000 pesos por su ininterrumpido consumo hídrico desde 1999 hasta esa fecha -incluyendo los intereses generados por mora-; el cuadro tarifario aplicado era el más beneficioso para la empresa, dado que el agua utilizada era facturada como 'agua de riego', con un costo de apenas 1 centavo por metro cúbico. Un año después, el ente estatal reanudó sus reclamos y reestructuró el esquema tarifario, llevándolo esta vez a 90 centavos de peso por metro cúbico y solicitando a la empresa que regularizara la deuda correspondiente al año 2011 -1.784.477,8 pesos por el consumo de 2.500 .000 metros cúbicos de agua(EL ESQUIÚ, 2012d, s/p; EL INVERSOR ON LINE, 2015, s/p).

Obstando el infructuoso desenlace de las tentativas previas, los guarismos citados son ostensiblemente inferiores a las estimaciones académicas internacionales; de hecho, a finales de la década de 1990 el valor del metro cúbico de agua rondaba los 0,67 dólares (COSTANZA, 1997, citada por MERENSON, 2011 , p. 11 $)^{10}$. Si se considera este dato en función de los 18 años de actividad de Salar del Hombre Muerto (1999-2016) y el volumen hídrico consumido en idéntico lapso (47.934.720 m3), Minera del Altiplano adeudaría 32.116.262,4 dólares, esto es, una cifra 71,9 veces superior a la exigida por el gobierno catamarqueño para el período 1999-2011 (446.927,8 dólares) y 18,4 veces más grande que el monto que en función de la inalterabilidad del cuadro tarifario pese a la subsiguiente evolución del tipo de cambio en Argentina- correspondería para las casi dos décadas de explotación del yacimiento (1.744.519,4 dólares). A la luz de estos datos, queda claro que uno de los principales mecanismos de acumulación por desposesión de la minería del litio en Salar del Hombre Muerto no es otra cosa que el liso y llano saqueo del agua.

\section{CONCLUSIONES}

Obedeciendo a la lógica del orden global y la división internacional del trabajo, los usos extractivos del territorio en los países periféricos frecuentemente operan como formas o modalidades de acumulación por desposesión. En la Argentina, la minería metalífera de exportación no evade esa ley general. Pieza clave de la oleada de acumulación por despojo iniciada por el neoliberalismo en la década de 1990 y continuada por el neo-desarrollismo de albores del Siglo XXI, el boom del litio ha contribuido a reorganizar el mapa minero mundial para satisfacer las demandas de las compañías tecnológicas y las corporaciones automotrices transnacionales, a la vez que ha convertido a este mineral en un insumo prácticamente indispensable para la reproducción del sistema capitalista contemporáneo. Segunda exportadora mundial, la Puna Argentina forma parte del preciado 'triángulo del litio', donde pululan empresas mineras y automotrices extranjeras ávidas de procurarse el control oligopólico de las reservas. En tal sentido, el estudio de caso de la compañía

\footnotetext{
${ }^{10}$ Este valor de referencia es la tarifa actualmente vigente en los Estados Unidos. Sin embargo, la situación se agravaría aún más si se consideraran los cuadros tarifarios vigentes en España (1,01 a 2,50 euros por metro cúbico), Italia ( 1,18 euros), Japón (más de 3 euros para usuarios industriales), Alemania (4,46 euros) y la ciudad inglesa de Glasgow (5,28 euros).

Estudos Geográficos, Rio Claro, 15(1): 157-183, jan./jun. 2017 (ISSN 1678-698X)

http://www.periodicos.rc.biblioteca.unesp.br/index.php/estgeo
} 
estadounidense FMC Lithium y sus operaciones en Salar del Hombre Muerto -sexto reservorio de litio del planeta, el principal y más antiguo yacimiento de dicho mineral en explotación en el país- no sólo brinda sólidos elementos empíricos acerca de las dinámicas expropiatorias intrínsecas al modelo, sino que proporciona los primeros atisbos de una realidad que -de continuar la fiebre por esta materia prima y las políticas domésticas actuales- se tornará harto frecuente en el noroeste argentino.

Conforme a los resultados obtenidos por este trabajo, la minería del litio condensa dentro de sí buena parte de los mecanismos de acumulación por desposesión identificados por Harvey (2004, p. 116-118), a saber: privatización de la tierra; apropiación neocolonial e imperial de bienes comunes (tierra, subsuelo, agua); extranjerización del patrimonio público; y degradación del hábitat. De estos dispositivos, los tres primeros se enmarcan en dinámicas de expropiación geográfica que insertan a los lugares en el mercado mundial bajo una lógica de economía de enclave. Continuando la (ya secular) tendencia histórica de reproducción de una división internacional del trabajo basada en el intercambio desigual de las materias primas de los países periféricos por los productos industrializados de las grandes potencias, el modelo superpone al territorio local su propia geometría espacial, compuesta de flujos y puntos valorizados en función de su capacidad de aportar recursos estratégicos no renovables a las cadenas productivas globalizadas del capital.

Sin embargo, esta suerte de 'colonias-commodities' están absolutamente alienadas de su entorno inmediato, tal como lo demuestran el escaso empleo directo generado, el carácter extra-provincial de la fuerza laboral contratada, la magra contribución fiscal al erario público, la persistencia de altas tasas de pobreza estructural y la ausencia de equipamiento, infraestructura y servicios básicos para la población. Impensables en pleno Siglo XXI, estas carencias reflejan la paradoja de un territorio que provee al mercado mundial de uno de los insumos actualmente más preciados de la economía global, pero que continúa tan ajeno a la modernidad como antaño y, por añadidura, excluye a sus habitantes de los mismos recursos materiales cuyo usufructo es garantizado a las firmas transnacionales por el propio Estado.

Otras dimensiones de la acumulación por desposesión asociada a la minería del litio dejan un saldo no menos grave. Condiciones generales como la singular naturaleza concesible de las reservas minerales argentinas -rasgo no compartido por los restantes países del triángulo del litio-, el extenso abanico de inauditos privilegios fiscales, tributarios, comerciales, financieros, políticos y territoriales otorgados a las empresas mineras, y los laxos controles burocráticos, se combinan con factores puntuales -regímenes promocionales provinciales, reintegros a las exportaciones, acceso diferencial a la provisión de energía a bajo costo- para forjar un andamiaje de reformas normativo-institucionales que juega un papel clave en la ecuación de rentabilidad del capital. Operando como dispositivos político-económicos del saqueo, estos mecanismos drenan al exterior riquezas que podría ser volcadas en el genuino desarrollo local y regional. El acaparamiento y sangría del recurso hídrico sella este proceso y subsume en un mismo fenómeno la producción política de rentabilidad y la desapropiación ecológica; así pues, el desmesurado y gratuito consumo de agua en el sector más desértico de la provincia de Catamarca revela claramente la perversidad de un modelo que, pese a hallarse aún en etapa embrionaria, ya está 
generando impactos socio-ambientales en otras áreas de la puna jujeña, salteña y catamarqueña aún más graves que los señalados en el caso aquí estudiado ${ }^{11}$.

Dado que la dinámica hidro-intensiva de la minería del litio degrada el frágil ecosistema de los salares y contamina las fuentes superficiales y subterráneas de agua, resulta claro que -en caso de que esta tendencia continúe y/o se expanda- el modelo hegemónico impedirá la reproducción de las condiciones materiales e inmateriales de existencia de las economías familiares de subsistencia y acabará por destruir la coherencia interna de los territorios aborígenes y campesinos andinos -el estadio final de la acumulación por desposesión-. En resumidas cuentas, toda la evidencia empírica disponible sugiere que la minería del litio, al despojar a territorios y grupos sociales de sus bienes comunes y derechos históricamente adquiridos y agravar la subordinación y dependencia económico-política y las problemáticas socio-ambientales locales, opera como un uso del territorio que es racional para los agentes hegemónicos beneficiados e irracional para todos los demás actores.

\section{BIBLIOGRAFÍA}

AGUILAR, F.; ZELLER, L. Litio. El nuevo horizonte minero. Dimensiones sociales, económicas y ambientales. Córdoba: Centro de Derechos Humanos y Ambiente, 2012. 76p.

\section{ALLAN, J. A. Virtual water: achieving a non-hydrocentric understanding of water allocation and management. 2003. Disponible en: <http://www.siwi.org/documents/Resources/Water_Front_Articles/2003/WF2- 3_Experts_View_on_Virtual_Water.pdf>. Acceso en: 20 jun. 2015.}

ANDRADA, L. Escenarios provinciales en la coyuntura. Provincia de Catamarca. Buenos Aires: Consejo Federal de Inversiones, 2002. 50p.

ARANDA, D. La fiebre del litio. Diario Página 12. Buenos Aires, 6 de junio de 2011. Disponible en: https://www.pagina12.com.ar/diario/sociedad/3-169555-2011-0606.html Acceso en: 15 abr. 2017.

ARÉVALO MOSCHELLA, L. S. Integración regional y recursos estratégicos. El caso del triángulo del litio. La Plata: VII Congreso del IRI / I Congreso del CoFEI / II Congreso de la FLAEI, 2015. 12p.

\section{BRUCKMAN, M. Recursos naturales y la geopolítica de la integración sudamericana. Lima: Fondo Editorial Mariatégui, 2012. 150p.}

BURCHARDT, H-J.; DIETZ, K. (Neo)extractivism - a new challenge for development theory from Latin America". Third World Quarterly, n. 35, v. 3, p.468-486, 2014.

\footnotetext{
${ }^{11}$ En efecto, en todo el noroeste argentino se observa una creciente puja por la tierra y el acceso al agua entre las comunidades aborígenes y las compañías mineras que se encuentran detrás de los recientes proyectos de exploración de litio. En las Salinas Grandes, se han reportado denuncias posteriormente constatadas de perforaciones que, con el aparente objetivo de prospección minera y/o evaluación hidro-geológica, han contaminado niveles salinos superficiales y acuíferos (MANRIQUE, 2014, p.39). Científicos de la universidad sueca de Lund detectaron que los acuíferos salteños de Salar de Pocitos, Olacapato, San Antonio de los Cobres y Polar Grande están contaminados por la presencia de litio, arsénico, cesio, rubidio y boro (LOS ANDES, 2011, $\mathrm{s} / \mathrm{p})$.

Estudos Geográficos, Rio Claro, 15(1): 157-183, jan./jun. 2017 (ISSN 1678—698X)

http://www.periodicos.rc.biblioteca.unesp.br/index.php/estgeo
} 
CAC. Perfiles exportadores provinciales 2010-2015. Buenos Aires: Cámara Argentina del Comercio, 2016. 150p.

CEPAL. Desarrollo de los recursos mineros de América Latina. Santiago de Chile: Comisión Económica Para América Latina y el Caribe, 1985. 154p.

COCHILCO. Antecedentes para una política pública en minerales estratégicos: litio. Santiago de Chile: Dirección de Estudios y Políticas Públicas, Comisión Chilena del Cobre, 2009. 46p.

CONTACTO MINERO. Litio; la materia prima del futuro enfrenta a Catamarca y Salta en disputa territorial. 2012. Disponible en: http://contactominero.com/?p=3512.

Acceso en: 12 may. 2017.

\section{DINREP. Necesidades Básicas Insatisfechas (NBI). Información censal del año} 2010 (versión ampliada con departamentales. Buenos Aires: Dirección Nacional de Relaciones Económicas con las Provincias, Subsecretaría de Relaciones con las Provincias, Ministerio de Economía y Finanzas Públicas de la Nación, 2014. 68p.

EL ANCASTI. Empresa minera deja aislados a pobladores. Diario El Ancasti, 9 de diciembre de 2005. San Fernando del Valle de Catamarca.

EL ESQUIÚ. Las cuentas pendientes con Catamarca. Diario El Esquiú, 13 de septiembre de 2012 (a). Disponible en:

http://www.elesquiu.com/sociedad/2012/9/13/cuentas-pendientes-catamarca82642.html. Acceso en: 22 abr. 2017.

EL ESQUIÚ. Minera del Altiplano se lleva riquezas y deja migajas para la provincia. Diario El Esquiú, 4 de septiembre de 2012 (b). Disponible en: http://www.elesquiu.com/sociedad/2012/9/4/minera-altiplano-lleva-riquezas-dejamigajas-para-provincia-81606.html. Acceso en: 22 abr. 2017.

EL ESQUIÚ. Antofagasta espera revertir la relación con la empresa norteamericana. Diario El Esquiú, 13 de septiembre de 2012 (c). Disponible en: http://www.elesquiu.com/sociedad/2012/9/13/antofagasta-espera-revertir-relacionempresa-norteamericana-82643.html. Acceso en: 22 abr. 2017.

EL ESQUIÚ. Minera FMC Lithium no pagó jamás el canon de agua. Diario El Esquiú, 17 de septiembre de 2012 (d). Disponible en:

http://www.elesquiu.com/politica/2012/9/17/minera-altiplano-pago-jamas-canonagua-catamarca-83097.html. Acceso en: 18 abr. 2014.

EL ESQUIÚ. Ponen a prueba el gasoducto que beneficiará a la Puna Catamarqueña. Diario El Esquiú, 17 de agosto de 2015 (a). Disponible en:

http://www.elesquiu.com/politica/2015/8/17/ponen-prueba-gasoducto-beneficia-punacatamarquena-191319.html. Acceso en: 22 abr. 2017.

EL ESQUIÚ. Histórico acuerdo con Minera del Altiplano. La empresa accedió a pagar el agua que consume con obras para Antofagasta. Diario El Esquiú, 6 de mayo de 2015 (b). Disponible en: 
http://www.elesquiu.com/politica/2015/5/6/historico-acuerdo-minera-altiplano182403.html. Acceso en: 22 abr. 2017.

EL ESQUIÚ. Distribuyeron más de 22 millones de pesos por regalías a los municipios. Diario El Esquiú, 26 de marzo de 2017. Disponible en: http://www.elesquiu.com/politica/2017/3/26/distribuyeron-millones-pesos-regaliasmunicipios-243115.html. Acceso en: 22 abr. 2017.

EL INVERSOR ON LINE. Minera agota el agua de Catamarca y se resiste a pagar la factura. 2015. Disponible en: http://www.eldestapeweb.com/minera-agota-el-aguacatamarca-y-se-resiste-pagar-la-factura-n2726. Acceso en: 22 abr. 2017.

FARN-CEDIB. El litio en la Puna Argentina y Boliviana. Principales implicancias de la explotación de litio en la zona. Fundación Ambiente y Recursos Naturales-Centro de Documentación e Información Bolivia, 2014. 46p.

GALLARDO, S. Extracción de litio en el norte argentino". Revista EXACTAmente, n. 48, s/p, 2011. Disponible en:

https://revistaexactamente.wordpress.com/2011/10/25/extraccion-de-litio-en-el-norteargentino/. Acceso en: 15 abr. 2017.

GUDYNAS, E. Diez tesis urgentes sobre el nuevo extractivismo. Contextos y demandas bajo el progresismo sudamericano actual. In: VVAA. Extractivismo, política y sociedad. Quito: Centro Andino de Acción Popular-Centro Latinoamericano de Ecología Social, 2009, p. 187-225

HARVEY, D. (2004). El nuevo imperialismo. Madrid: Akal. 170p.

INDEC. Censo Nacional de Población Hogares y Viviendas 2010. Base REDATAM. Disponible en: http://200.51.91.245/argbin/RpWebEngine.exe/PortalAction?\&MODE=MAIN\&BASE= CPV2010A\&MAIN=WebServerMain.inl. Acceso en: 10 mar. 2017.

LA UNIÓN DIGITAL. Denuncian contaminación y alteración del paisaje por parte de una empresa minera en el Salar del Hombre Muerto. 2014. Disponible en: http://launiondigital.com.ar/noticias/140703-denuncian-contaminacion-y-alteraciondel-paisaje-por-parte-una-empresa-minera-salar. Acceso en: 22 abr. 2017.

LOS ANDES. Advierten que hay altos niveles de litio en el agua de la cordillera. Diario Los Andes, 8 de abril de 2011. Disponible en:

http://archivo.losandes.com.ar/notas/2011/4/8/advierten-altos-niveles-litio-aguacordillera-argentina-561037.asp. Acceso en: 22 abr. 2017.

MACHADO ARÁOZ, H. El auge de la minería transnacional en América Latina. De la ecología política del neoliberalismo a la anatomía política del colonialismo. In:

ALIMONDA, H. (Coord.). La naturaleza colonizada. Ecología política y minería en América Latina. Buenos Aires: CICCUS-CLACSO, 2011, p. 135-179

MACHADO ARÁOZ, H.; SVAMPA, M.; VIALE, E.; GIRAUD, M.; WAGNER, L.; ANTONELLI, M.; GIARRACCA, N.; TEUBAL, M. 15 mitos y realidades de la minería transnacional en la Argentina. Guía para desmontar el imaginario

Estudos Geográficos, Rio Claro, 15(1): 157-183, jan./jun. 2017 (ISSN 1678-698X)

http://www.periodicos.rc.biblioteca.unesp.br/index.php/estgeo 
prominero. Buenos Aires: Editorial El Colectivo-Herramientas Ediciones, 2011. $104 p$.

MACHADO ARÁOZ, H. Orden neocolonial, extractivismo y ecología política de las emociones. Revista Brasileira de Sociología da Emoção, v. 12, n. 34, p.11-43, $2013 a$.

MACHADO ARÁOZ, H. Entre la fiebre del oro y el polvo de las voladuras... Cuerpos y emociones en contextos de mineralización. Revista Latinoamericana de Estudios sobre Cuerpos, Emociones y Sociedad, n. 11, a. 5, p.21-33, 2013b.

MANRIQUE, A. Explotación del litio, producción y comercialización de baterías de litio en Argentina. Mar del Plata: Universidad Nacional de Mar del Plata, 2014. $112 p$.

MARX, K. El capital. México, D.F: Fondo de Cultura Económica. 953p.

MECON. Complejos exportadores provinciales. Informes anuales 2010, 2011 y 2012. Buenos Aires: Ministerio de Economía y Finanzas Públicas. 202p.

MERENSON, C. Estimación del pasivo ambiental del cultivo de soja en Argentina. Buenos Aires: Centro de Estudios e Investigación Social Nelson Mandela, 2011. 13p.

MEyM. Situación actual y perspectivas. Mercado de litio. Buenos Aires: Ministerio de Economía de la Nación, 2017. 27p.

$\mathrm{MH}-\mathrm{INDEC}$. Complejos exportadores 2016. Informes Técnicos Comercio Exterior, v. 1, n. 34. Buenos Aires: Ministerio de Hacienda-Instituto Nacional de Estadística y Censos, 2017. 15p.

MAPA CONFLICTOS MINEROS. Proyecto Fénix-Minera del Altiplano. Observatorio Latinoamericano de Conflictos Mineros. 2017. Disponible en:

http://mapa.conflictosmineros.net/ocmal_db/?page=conflicto\&id=63. Acceso: $20 \mathrm{abr}$. 2017.

MORAES, A. C. R. Los circuitos espaciales de producción y los círculos de cooperación en el espacio. In: LIBERALI, A. M; YANES, L (Comp.). Aportes para el estudio del espacio socioeconómico. Buenos Aires: El Coloquio, 1988, p. 151177.

NACIF, F. El litio en Argentina: de insumo estratégico a commodity. Revista Herramienta, n. 54, s/p, 2014. Disponible en: http://www.herramienta.com.ar/revistaherramienta-n-54/el-litio-en-argentina-de-insumo-estrategico-commodity. Acceso en: 15 abr. 2015.

NALM. En Catamarca también saquean el litio. No a la Mina, 2012. Disponible en: http://www.noalamina.org/mineria-argentina/catamarca/item/9859-en-catamarcatambien-saquean-el-litio. Acceso en: 10 mar. 2017. 
NALM. La minera FMC ampliará un gasoducto para su beneficio en la Puna. No a la Mina, 2013. Disponible en: http://www.noalamina.org/mineriaargentina/salta/item/11179-la-minera-fmc-ampliara-un-gasoducto-para-su-beneficioen-la-puna. Acceso en: 10 mar. 2017.

NALM. Catamarca y San Juan reciben más fondos de la Nación que de las empresas mineras. No a la Mina, 2014. Disponible en:

http://www.noalamina.org/mineria-argentina/catamarca/item/13085-catamarca-y-sanjuan-reciben-mas-fondos-de-la-nacion-que-de-las-empresas-mineras. Acceso en: 10 mar. 2017.

REDAJ. Litio, la paradoja de la abundancia. Red de Asistencia Jurídica contra la Megaminería, 2011. 21p.

SANTOS, M. A natureza do espaço. Técnica e tempo, razão e emoção. São Paulo: Hucitec, 1996. 260p.

SANTOS, M.; SILVEIRA, M. L. O Brasil. Território e sociedade no início do século XXI. Rio de Janeiro-São Paulo: Record, 2001. 471p.

SEVARES, J.; KRZEMIEN, J. P. El litio en Argentina: oportunidades y desafíos de un recurso estratégico. Realidad Económica, n. 272, p.127-157, 2012.

SILVEIRA, M. L. Concretude territorial, regulação e densidade normativa. Experimental, a. I, n. 2, p.35-45, 1997.

SILVEIRA, M. L. Um país, uma região. Fim de século e modernidades na Argentina. São Paulo: LABOPLAN-USP, 1999. 488p.

SILVEIRA, M. L. O espaço da globalização: usos diversos, comando único. In: SANTOS, M. (Comp.). Cidadania e globalização. Bauru: Saraiva, 2000, p. 121-127.

SVAMPA, M.; BOTTARO, L.; SOLÁ ÁLVAREZ, M. La problemática de la minería a cielo abierto: modelo de desarrollo, territorio y discursos dominantes. In: SVAMPA, M.; ANTONELLI, M. (Ed.). Minería transnacional, narrativas del desarrollo y resistencias sociales. Buenos Aires: Biblos, 2009, p. 29-50.

TAPIA, M.; QUIROGA, D. E.; SÁNCHEZ, D. La gran minería ¿sinónimo de desarrollo?: la aplicación del Índice de Calidad de Vida (ICV) en el caso de Antofagasta de la Sierra, Provincia de Catamarca. RIEM, n. 12, a. VI, p.41-66, 2015.

TRADEMAP. Estadísticas del comercio para el desarrollo internacional de las empresas. 2017. Disponible en:

http://www.trademap.org/Index.aspx?lang=es\&AspxAutoDetectCookieSupport=1. Acceso en: 10 abr. 2017.

ZÍCARI, J. Neoextractivismo en Sudamérica. El caso del litio. Revista NERA, a. 18, n. 29, p.10-47, 2015. 